\title{
Güçler Temelli Yaklaşım ve Güçlendirme: Kolektif Kimlik, Bilgi-Beceri, Benlik Kavramı, Eleştirel Farkındalık, Harekete Geçme ${ }^{1}$
}

\author{
DOI: $10.26466 /$ opus.597190
}

*

\begin{abstract}
Mehmet Kırlığlu *
* Dr. Öğr. Üyesi, Necmettin Erbakan Üniversitesi, Sağlık Bilimleri Fakültesi,Meram/Konya/Türkiye E-Posta: drkirlioglu@gmail.com

ORCID: 0000-0003-0130-0841

Öz
\end{abstract}

Bu çalışma, güçler temelli yaklaşımın unsurları akılda tutularak güçlendirme kavramını çeşitli boyutları ele almayı amaçlamaktadır. Güçlendirme kavramı çokça Türkçe literatürde yer almasına rağmen güçlendirmenin kolektif kimlik, bilgi ve beceri, benlik kavramı, eleştirel farkındalı ve harekete geçme boyutları daha önce ele alınmamıştır. Güçlendirme kavramına zenginlik katacă̆ı düşünülen bu boyutlarm hem sosyal hizmet literatürüne hem de sosyal hizmet uzmanlarmnn uygulamalarnnda yarar sağlayacă̆ı düşünülmektedir. Güçler temelli yaklaşım sosyal yapılandırmacı görüşe dayandırılarak ortaya çıkmıştır. Güçler temelli yaklaşım sosyal hizmet uzmanını müracaatçıların sorunları ya da kusurları odaklanmaktansa güçler, beceriler, kaynaklar ve başarllara odaklanan etkileşimler ve müdahalelere doğru yönlendiren bir çalışma yöntemidir. Müracaatçıların güçlerini belirlerken sosyal hizmet uzmanları müracaatçıların görünen güçlerinin ötesine odaklanmalıdır. Ayrıca müracaatçıların kapasiteleri, yeterlilikleri, nitelikleri, umutları, olasılıkları, kaynakları, yılmazlıkları, ihtiyatların dikkatli bir şekilde gözden geçirmelidir. Diğer taraftan bireyin içinde güç olduğu düşüncesi güçlendirme açısından bir çıkış noktasıdır. Biribiri ile ilişkili olduğu düşünülen bu iki kavramın birlikte ele alınması önemli görülmektedir. Literatürde güçlendirmenin çeşitli boyutlarından bahsedilmektedir. Bu çalışmada güçlendirmenin boyutları, Frans (1993) tarafından kavramsallaştırılan ve literatüre kazandırılan beş boyut üzerinden anlatılmaya çalışılmıştır. Bu boyutlar kolektif kimlik, bilgi ve beceri, benlik kavramı, eleştirel farkındalık ve harekete geçme şeklinde adlandırllmaktadır. Literatürde bahsedilen diğer boyutların da yine sosyal hizmet uzmanı perspektifini göz önünde tutarak değerlendirilmesi önerilmektedir.

Anahtar Kelimeler: Güç, Güçlendirme, Güçler temelli yaklaşım, Sosyal hizmet, Sosyal hizmet uzmanı

\footnotetext{
${ }^{1}$ Bu çalışma Sosyal Hizmet Uzmanlarının Kişsisel ve Mesleki Güç Algılarının Bazı Değişkenlere Göre incelenmesi adlı doktora tezinin bir bölümünden oluşmaktadır.
} 


\title{
A Strength Based Approach and Empowerment: Collective Identity, Knowledge-Skills, Self-Concept, Critical Awareness, Propensity to Act
}

\begin{abstract}
This study aims to address the concept of empowerment by considering various aspects of a strength based approach. Although the concept of empowerment is widely included in the Turkish literature, the dimensions of collective identity, knowledge and skills, self concept, critical awareness and propensity to act have not been previously addressed. It is thought that these dimensions, which are thought to add richness to the concept of empowerment, will benefit both the social work literature and the practices of social workers. A strength based approach emerged based on social constructivist view. A strenght based approach is a way of working that directs the social worker towards interactions and interventions focusing on powers, skills, resources and achievements rather than focusing on the problems or flaws of the clients. In determining the clients' strengths, social workers should focus beyond the apparent powers of the clients. Furthermore, capacities, competencies, character, promise, possibility, resources, resilience, reserve of the clients should be carefully reviewed. On the other hand, the idea that there is power within the individual is a starting point in terms of empowerment. It is important that these two concepts, which are thought to be related to each other, be handled together. Various aspects of empowerment are mentioned in the literature. In this study, the dimensions of empowerment are explained through five dimensions conceptualized by Frans (1993). These dimensions are called collective identity, knowledge and skills, self concept, critical awareness and propensity to act. It is suggested that the other dimensions mentioned in the literature should be evaluated by considering the perspective of social worker.
\end{abstract}

Keywords: Power, Empowerment, A strength based approach, Social work, Social worker 


\section{Giriş}

Sosyal yapılandırmacı görüşe (Berger ve Luckmann, 1967) dayandırılarak ortaya çıkan güçler temelli yaklaşım (a strength based approach), sosyal hizmet uzmanını müracaatçıların sorunları ya da kusurları odaklanmaktansa güçler, beceriler, kaynaklar ve başarılara odaklanan etkileşimler ve müdahalelere doğru yönlendiren bir çalışma yöntemidir (Chapin, 1995; Cowger, 1994; Goldstein, 1990; Teater, 2015; Weick vd., 1989). Çevrenin birey üzerindeki etkisinin fark edilmesiyle teori ve uygulamada meydana gelen değişimler, sosyal hizmet mesleğinin odağını bireysellikten ziyade sosyal koşulların ötesine taşımış ve güç, eşitsizlik ve sosyal adalet gibi yeni değerlerin ortaya çıkmasını sağlamıştır. Buradaki temel amaç bireyi dikkate almamak değil, bireyi kültürel ve yapısal etmenler gibi daha geniş bir bağlamda ele almak ve müracaatçıların daha güçlü bir etkiye sahip olmalarını sağlamaktır (Thompson, 2013). Bu nedenle güçler temelli yaklaşım sosyal hizmet uygulamasında problem odaklı yaklaşıma karşı olarak öne sürülmüş bir yaklaşımdır (Teater, 2015).

Müracaatçıya yardım etmede kullanıla gelen medikal model benzeri çoğu yaklaşımın müracaatçının olumlu ve işlevsel yönlerinden ziyade eksikliklere yöneldiği yani neyin yanlış gittiğine odaklandığı belirtilmektedir (Sheafor ve Horejsi, 2014). Örneğin sosyal hizmet uzmanları da dahil olmak üzere bir çok meslek elemanı çok uzunca bir süre müracaatçları ile ilgili konularda patoloji, eksiklikler ve müracaatçının işlevsizliği üzerinde odaklanmışlardır. Bunun nedeni olarak Freudcu psikolojinin kendi ve kendinden sonraki dönemi büyük ölçüde etkilemesi ileri sürülmekte olup aynı zamanda Freudcu psikolojinin gücü tanımlayacak çok az kavramı barındırdığı belirtilmektedir (Duyan vd., 2008; Zastrow, 2013). Ancak patoloji üzerine odaklanmak, müracaatçıların kendi potansiyellerini geliştirme hakları olduğu konusundaki sosyal hizmetin değer yargısı ile çelişmektedir (Zastrow, 2013). Ek olarak güçler temelli yaklaşım ile kendi kaderini tayin hakkı arasında pozitif yönlü bir ilişki bulunmaktadır (Greene ve Lee, 2002). Bu noktada medikal model insanların yapamadıklarına odaklanması, bağımlılık fikrini pekiştirmesi, bireyci olması, toplumun verdiği tepkinin engelleyici etkisini ihmal etmesi konularında eleştirilmiştir (Thompson, 
2016). Güçler temelli yaklaşım sosyal hizmet uzmanı için görünenin ötesine ulaşmaya, müracaatçılar için ise anlamlı bir gelecek için yapabilirliklere odaklanmaktadır. Böylece bu yaklaşım müracaatçıları baskı, ayrımcılık, ırkçılık ve damgalamanın olumsuz sonuçlarından korumak ve kurtarmak için bir araç görevi görebilmektedir (Teater, 2015).

Literatürde gücün kendisi ile bağlantılı olarak kullanım yöntemine de vurgu yapılmaktadır. Güçler temelli yaklaşımda uzman-müracaatçı ilişkisi ortaklık ve işbirliği esasına dayanmaktadır. Geleneksel yaklaşımların aksine güçler temelli yaklaşımda meslek elemanının uzmanlığından ziyade müracaatçının kendi koşullarının üzerinde uzman olduğu, yapılacak müdahaleler konusunda karar verici konumda olduğu belirtilmektedir (Sheafor ve Horejsi, 2014). Çünkü güçler temelli yaklaşım paternalizm karşıtıdır (Toplum veya aile yönetiminde kararların, rehber ve ideal kabul edilen kişi veya kişilerce alınmasını öngören yönetim sisteminin adıdır) (Zastrow, 2013). Güçlere odaklanmanın önemi üzerinde durulmaktadır çünkü tersi durumdaki güçsüzlük kavramı, kendini suçlama, her türlü konu hakkında güvensizlik, kaynaklar konusunda bilgisizlik, oy hakkının bulunmaması, ekonomik darboğaz ve sosyo-politik mücadeleye olan inançsızlık gibi birçok boyuta vurgu yapmaktadır (Dubois ve Miley, 2013; Miley vd., 2016). Buna ek olarak ortaklık ve işbirliğine dayalı güç, birbiri ile ilişkili olup bu da tinsellik gibi özden gelen gücü ve yapabilme gücünü geliştirmek açısından oldukça faydalıdır. Bunun tersi ise paternalizmdir ve bu da gücü baskı olarak kullanmayı kapsamaktadır (Thompson, 2016).

Thompson (2016) gücün sıfır toplamlı bir kavram olmadığını, 'sosyal hizmet uzmanını güçlü, müracaatçıyı güçsüz' konumlandıran anlayıştan 'birlikte güçlü olabiliriz' anlayışına geçilebileceği üzerinde durur. Ayrıca güç dinamikleri ve güç eksikliğinin bireysel/intrapsişik, kişilerarası/etkileşimsel, ailevi, etnik/kültürel ve toplumsal işlevlerin yerine getirilmesinde önemli bir etken olduğu belirtilmektedir (Pinderhughes, 1983).

Müracaatçıların güçlerini belirlerken sosyal hizmet uzmanları, müracaatçların görünen güçlerinin ötesine odaklanmalı ve müracaatçların kısaca C (capacities, competencies, character), P (promise, possibility), $\mathrm{R}$ (resources, resilience, reserve) olarak ifade edilen kapasiteleri, yeterlilikleri, nitelikleri, umutları, olasılıkları, kaynakları, 
yılmazlıkları, ihtiyatlarını dikkatli bir şekilde gözden geçirmelidir (Saleebey, 2000, 2006). Güçlerin, ne kadar zorlu görünürse görünsün her ortamda bulunacağı varsayılır (Sheafor ve Horejsi, 2014). Örneğin bireyler için güçler büyük amaçlar, yetkinlikler ve güven iken, gruplar için fırsatlar ve güven, toplumlar için fırsatlar, toplumsal ağlar, kaynaklar ve somut hizmetler olabilir (Teater, 2015). Hatta ve hatta travmatik yaşam olaylarının bireyin yaşam kalitesini olumsuz bir şekilde etkileyebileceği belirtilirken bu yaşam olaylarının dahi bireysel güç için bir kaynak olabileceği ifade edilmektedir. Diğer bir ifade ile bir kişinin yaşam güçlüklerinin üstesinden gelmede gösterebileceği becerinin en üst stntrmın bilinemeyeceği vurgulanmaktadır (Sheafor ve Horejsi, 2014). Bu noktada sosyal hizmet uzmanlarına hem müracaatçı değerlendirmesi hem de kendisi için yardımcı olabilecek güçlerin bulunabileceği olası alanlar aşağıda belirtilmiştir.

Tablo 1. Güçlerin bulunabileceği olası alanlar

\begin{tabular}{ll}
\hline Kişilerin bildikleri/öğrendikleri & Eğitim ve işyeri \\
\hline Nitelikler, karakter, erdemler & Geçmiş yaşamındaki başarıları \\
\hline Yetenekler & Kararlılık \\
\hline Kişisel Haysiyet & Tutku \\
\hline Maneviyat & Merak \\
\hline Başa çkma becerileri & Kanaat \\
\hline Kültürel ve kişisel hikayeler, töreler & Esneklik \\
\hline Topluluk & Sorun çözmeye dair geçmiş girişimler \\
\hline Destek Ağ1 & Sosyo-politik destekler/kaynaklar \\
\hline Motivasyon & Sağlı \\
\hline Kişilerarası ilişkiler & Fursatlar \\
\hline Yılmazlı & Ümitler \\
\hline
\end{tabular}

Kaynak: Teater (2015)

Belirli koşullar altında hemen hemen her şeyin güç olarak düşünülebileceği ileri sürülmektedir. Güçlerin bulunabileceği çeşitli alanlar aşağıda sıralanmaktadır (Blum, 1998; Canda, 2006; Saleebey, 2012; Thompson, 2013; Wolin ve Wolin, 1998; Wolin ve Wolin, 2010):

İnsanlarn kendileri ve diğerleri ile ilgili öğrendikleri: İnsanlar başarıların yanı sıra göğüs gerdikleri zorluklardan da bir şeyler öğrenirler. Yıl- 
mazlık (dayanıklılık), içsel ve çevresel kaynakların etkileşiminden ve bireylerin karşılaştığı risk faktörlerinden kaynaklanmaktadır.

Bireysel nitelikler, özellikler, güçler: Zor bir durumu atlatırken insanlar, kimi yeteneklerinin, kazançlarının ya da kaynaklarının farkına varırlar. Bu sayede insanlar, zorluklarla baş edebilmek için yeni güçler ve kaynaklar geliştirirler. Bu konuda yaratıcılık, maneviyat, mizah, yardımseverlik vb. örnekler verilebilir.

İnsanların çevresi hakkında bildikleri şeyler: Bilgi (knowledge), eğitim, kültür ve mevcut deneyimlerimizi de kapsayacak şekilde birçok kaynaktan oluşmaktadır. Çevremiz ile ilgili öğrenme sürecinde beceri ve yeteneklerimizi geliştiririz. Örneğin, konut sistemi hakkında müracaatçımız sandığımızdan daha fazla bilgiye sahip olabilir. Bu bilgi sürecinin müracaatçıdan uzmana doğru çok sık olması müracaatçının buyruğu altına girmeye neden olabilir. Bu durum gözlemleyerek ve sorarak belirlenmelidir.

Insanların sahip oldukları yetenekler: Çoğu zaman, insanların şarkı söyleme, yazma, resim yapma, hikâye anlatma vb. gibi şaşırtıcı yeteneklere sahip olduğunu deneyimleyebiliriz. Birçok zaman da insanların bu yeteneklerinden bahsetmediğine şahit oluruz. Çünkü insanlar bu yeteneklerinin tartışılan konu ile ilgili uyumlu olmadığını düşünürler. Bu yetenekleri sormaz isek, bu güçleri harekete geçirme fırsatını da kaçırmış oluruz. $\mathrm{Bu}$ yetenekler müracaatçının arzuları ile bağlantılı olmayabilir. Ancak müracaatçının arzularını karşılamada ve amaçlarına ulaşmada yardım etmek için daha fazla kaynak ve araç olanağı sunar.

Bireysel ve kültürel anlatılar ve törensel bilgiler: Bu tür güçler sağlamlı̆̆ın, yol göstermenin, ait olma hissinin ve bireyin dünyadaki yerinin kaynaklarındandır. Anlatılar, mitler ve kültürel hikayeler; güçlükler üzerinden kimliğin, amacın ve ilhamın kaynağı olabilir.

Özsaygi: İnsanlar engelleyici durumların üstesinden geldikleri zaman ya da zorlu süreçten daha iyi bir duruma geldiklerinde başarma ve gurur hissi geliştirirler. Bu durum kimi yazarlar tarafından hayatta kalanın 
gururu olarak tarif edilmektedir (Blum, 1998; Wolin ve Wolin, 1998; Wolin ve Wolin, 2010).

Topluluk: Topluluklarda fiziksel, kişilerarası, kurumsal güçler gibi değerlendirmeye dahil edilmesi gereken birçok değerli nitelikler bulunmaktadır. İnsanlar 'yardım alma'nın yanı sıra 'yardım verme'den de yararlanabileceği, bu durumun onların bağlılıklarını ve güçlerini geliştirebileceği ifade edilmektedir.

Tinsellik: Tinsellik yaşama verilen anlam, "kimim ben?" sorusuna geliştirilen anlayış ve daha büyük resimde nerede durduğumuzla ilgidir (Thompson, 2013). Tinsellik müracaatçılar için pozitif bir gelecek imkânını var eden, umut ve inancı içinde barındıran gücün ve yılmazlığın kuvvetli bir kaynağıdır. Tinsellik bireyin biyolojik, psikolojik, sosyal, kültürel ve politik yönlerini içeren ve aynı zamanda bunların ötesine geçen bütüncül bir yaklaşımla tanımlanmaktadır (Canda, 2006). Tinsellik aynı zamanda zirve deneyimlerde, engin keşiflerde (ve bunun gibileri) dışa vurulabilen anlam ve deneyimleri bulma ile ilgilidir ki bizi hayatın gizemi ve karmaşıklığını keşfetmeye davet eder. Bu nedenle, müracaatçılarımız tinsellikten bahsettiğinde, müracaatçılarımızı dinlemeliyiz ve müracaatçıların inanç ve uygulamalarını saygıyla keşfetmek için motive olmalıyız. Literatürde bu bağlamda tinsellik odağında müracaatçı için önemli olan noktalara odaklanmanın önemi üzerinde durulmaktadır (Saleebey, 2012).

Güçler temelli yaklaşımla değerlendirme yapabilmek için bir takım ilkeler sunulmaktadır. Bunlar (Cowger, 1994; Saleebey, 1997; Sullivan, 1992; Teater, 2015; Weick vd., 1989):

- Müracaatçının bakış açısına öncelik vermek,

- Müracaatçıya inanmak,

- Müracaatçının ne istediğini, arzularını, amaçlarını ve hayallerini keşfetmek,

- Değerlendirmenin odağını bireysel ve çevresel güçlere yöneltmek,

- Çok boyutlu güçler değerlendirmesi yapmak,

- Müracaatçının anlayabileceği bir dil kullanmak,

- Suçlamaktan kaçınmak,

- Sebep-sonuç şeklinde düşünmekten kaçınmak,

- Teşhis etmekten ve etiketlemekten kaçınmak: 
Bu noktada sorunlara özellikle de teşhis koymaya yönelik yaftalara odaklanmanın müracaatçılar üzerinde son derece olumsuz etki bırakabileceği, bu nedenle de sosyal hizmet uzmanlarının güçler dilini kullanmaya devam etmek için çözüm odaklı soruları kullanabileceği belirtilmektedir.

- Karşılıklı işbirliği ilişkisi kurmak,

- Müracaatçılara yaşamın sorunları ile başa çıkabilmelerine dair bir umut sunmak,

- Müracaatçıların değişime dair doğuştan gelen yetilere sahip olduklarını fark etmelerine yardımcı olmak, bireyi bir yafta ya da teşhisin zincirlerinden kurtarmak ve bireye kendini gerçekleştirme fırsatını sunabilmek,

- Hizmetleri, topluluk içinde sunmak ve müracaatçların topluluk içinde var olma hakları olduğunu tanımak suretiyle damgalanmaktan sıyrılmasını sağlamak,

- Müracaatçıların kaygılarının çözümünü geleneksel tedavi sistemleri yerine topluluklarda aramak:

Bu durum müracaatçıyı toplulukla daha da fazla bütünleştirir ve insanlıktan daha az ayrışmış hissetmelerini sağlar. Müracaatçılarının topluluktaki fırsatları aramalarına yardımcı olma ve geleneksel hizmet kurgusunun ötesinde düşünebilme sorumluluğunun sosyal hizmet uzmanında olduğu unutulmamalıdır.

İçsel ve dışsal güçleri keşfetmek için kullanılabilecek çeşitli sorular Çözüm Odaklı Terapi'den (Cade ve O'Hanlon, 1993; Nunnally vd., 1986) esinlenerek oluşturulmuş olup sosyal hizmet uygulamasında güçleri keşfetmeye yönelik aşağıdaki sorulardan faydanıldığı belirtilmektedir. Bu noktada da güçleri keşfetmeye yönelik soruların sonsuz olduğunun unutulmaması vurgulanmaktadır (De Jong ve Miller, 1995; Saleebey, 2006; Teater, 2015):

Hayatta kalma soruları: Gögüs gerdiğin zorluklar karşısında hayatta kalmayı ya da bu zorlukların üstesinden gelmeyi nasıl başardın? Zorluklar karşısında bu mücadeleni sürdürürken kendin ve dünyan hakkında neler öğrendin?

Destek soruları: Güvenebileceğin insanlar kimlerdir? Kimler senin anlaşılmış, desteklenmiş ya da cesaretlendirilmiş hissetmeni sağlayabilir? 
İstisna soruları: Hayatında iyiye giden şeyler olduğu zamanlarda farklı olan neler vard1?

Olasılık soruları: Hayatında neyi başarmak istiyorsun? Geleceğin ya da ailenin geleceği için umutların nelerdir?

Saygı soruları: Kendin hakkında seni ne gururlandırmaktadır? Senin hakkında insanlar pozitif olarak ne söylerler?

Bakış açısı soruları: Mevcut durumun hakkında düşüncelerin nelerdir?

Değişim sorularn: Nelerin değişim için gerekli olduğunu düşünüyorsun? Bunun olabilmesi için neler yapabilirsin?

Sosyal hizmet uzmanları ön değerlendirme sürecinde müracaatçının güçlerini de düşünerek değerlendirmesini yaparlar ve müracaatçının güçlüklerini çözümleyebilmek amacıyla güç ve kaynaklara odaklanırlar (Zastrow, 2013). Bu noktada Rapp ve diğerleri (2006) güçler değerlendirmesine yedi yaşam alanın dahil etmektedirler. Bunlar içerisinde günlük yaşam durumu, mali durum, mesleki/eğitimsel durum, sosyal destekler, sağlık, serbest zaman/eğlence ve tinsellik yer almaktadır. Bu yaşam alanları zamansal sıralama ile ilişkili olup geçmiş zaman (Geçmişten ne kullandım?), şimdiki zaman (Bugün neler oluyor? Şimdi neler ulaşılabilir?) ve gelecek zaman (Ne yapmak isterim?) olmak üzere ele alınmaktadır. Bu kullanılan araç diğer değerlendirme araçları ile benzer olmayıp güçler değerlendirmesini geliştirme süreci için aynı zamanda eşsizdir. Çünkü bireylerin iyi yönlerini güçlendiren içsel bir amaca sahiptir.

Güçler temelli değerlendirme, müracaatçıdaki inançtan ileri gelmek zorundadır ve müracaatçı için hüküm ya da yargı niteliğinde olmamalıdır. Bu soruları tekrar etmek ya da güçler temelli formları doldurmak güçler yaklaşımı çerçevesinde çalışıldığı anlamına gelmez. Güçler temelli değerlendirmenin özünde olan şey müracaatçının potansiyeline etki edecek olan içten gelen inançtır. Güçler hakkında düşünmek müracaatçlların hangi amaç ve ideallere sahip olduğunu, yaşamlarındaki umut ve imkanları yansıtan şeylerin neler olduğunu anlamak ile başlar. Bu süreçte, müracaatçılar kendileri için yeni imkanları keşfedebilirler ya da geliştirebilirler ve daha iyi bir yaşam kalitesine doğru değişim gösterebilirler (De Jong ve Miller, 1995; Saleebey, 2006; Teater, 2015). Bu çerçevede güçlendirme yaklaşımının uygulamada 
kullanımının basitçe bir soru-cevap pratiğinden oluşmadığı, bunun ötesinde yaşamdaki unsurlara dokunmayı içerdiği belirtilebilir.

$\mathrm{Bu}$ çalışma, yukarıda ifade edilen genelde güçler temelli yaklaşımın unsurları özelde ise 'güçler' akılda tutularak güçlendirme kavramını çeşitli boyutları ele almayı amaçlamaktadır. Güçlendirme kavramı çokça Türkçe literatürde yer almasına rağmen güçlendirmenin kolektif kimlik, bilgi ve beceri, benlik kavramı, eleştirel farkındalık ve harekete geçme boyutları daha önce ele alınmamıştır. Güçlendirme kavramına zenginlik katacağı düşünülen bu boyutların hem sosyal hizmet literatürüne hem de sosyal hizmet uzmanlarının uygulamalarında yarar sağlayacağ düşünülmektedir.

\section{Güçlendirme}

Güçlendirme kavramın kökeninin aydınlanmaya kadar dayandığı belirtilmektedir. Aydınlanmanın temelde insana değer vermesi ve insanın daha insancil koşullarda yaşabilmesi için bireyin içinde güç olduğu düşüncesi güçlendirme açısından bir çıkış noktasıdır (İçağasıoğlu-Çoban ve Buz, 2008). Özellikle 18.yüzyılda yaygın olan karşılıklı yardım ve topluluk hareketlerinde güçlendirmenin köklerinin bir gövdeye oturduğu belirtilmektedir (Adams, 2003).

Kişisel ve kolektif hedeflere ulaşmak için kaynakları, stratejileri ve yetkinlikleri geliştirmenin güçlendirmenin merkezinde yer aldığı belirtilmektedir (Lee, 2001). Güçlendirme, bireylerin, kurumların ve toplulukların daha fazla kontrol, etkinlik ve sosyal adalet kazandığı aktif, katılımcı bir süreçtir (Solomon, 1976). Adams (2003) güçlendirmeyi bireylerin, grupların ve/veya toplulukların kendi koşullarının kontrolünü ele geçirip kendi hedeflerine ulaşabilmelerini sağlayan araçlar olarak tanımlamakta ve böylece yaşamlarının kalitesini en üst düzeye çıkarmak için kendilerine ve başkalarına yardımcı olmaya çalışabileceklerini ifade etmektedir. Bu noktada kendi kendine yardım edebilme güçlendirmede önemli bir husus olarak karşımıza çıkmaktadır (Payne, 2005; Solomon, 1976). Ayrıca güçlendirmenin, süreç ve amacı bütünleştiren bir unsur olduğu ve bu unsurun yapılandırılmış güçsüzlüklere karşı çıtı̆̆g belirtilmektedir (Frans, 1993). Anuradha (2004) güçlendirmeyi, kişilerin kontrolü ele geçirme süreci olarak belirtmekte olup diğer bir ifade ile 
insanların, organizasyonların ve toplumların hayatları üzerinde egemenlik kazanma biçimi olarak ifade etmektedir. Sosyal hizmet uygulamasında Barker (1995) güçlendirmeyi bireylerin, ailelerin, grupların ve toplulukların bireysel, bireyler arası, sosyo-ekonomik ve politik güçlerini arttırmak ve koşullarını iyileştirmeye yönelik etki geliştirmeye odaklanan yardım süreci olarak tanımlamaktadır. Gutierrez (1990) güçlendirmeyi bireylerin kendi yaşam durumlarını geliştirmek için harekete geçebilsinler diye kişisel, kişilerarası ve sosyo-politik güçlerinin arttırılması süreci olarak tanımlanmaktadır. Güdek (2013) ve Duyan (2010) ise güçlendirmenin sözcük anlamı olarak 'güç' kökünden geldiğini ve var olan bir şeyi ya da durumu daha güçlü hale getirmek anlamına geldiğini belirtmektedirler.

Sosyal hizmet uzmanları için uygulama sürecinde müracaatçıda değişim oluşturulurken sürece en yardımcı olacak şeyin müracaatçının potansiyeli ve becerileri olduğu belirtilmekte, söz konusu değişim müracaatçının karar ve eylemleri doğrultusunda şekilleneceğinden müracaatçının kendi güçlü yönleri ve güçlerinin farkında olmasının önemi vurgulanmaktadır (Sheafor ve Horejsi, 2014).

Sosyal hizmet uzmanları, uygulamalarını düşünümsel hale getirmek için güçlendirmeye ihtiyaç duymaktadır (Adams, 2003). Blundo (2001) güçlendirme yaklaşımının, sosyal hizmette müracaatçıya değer veren ve onunla işbirliği yapan bir yaklaşımla, sosyal hizmeti temel değerlerine geri getirebilmeyi amaçladığını belirtmektedir (Teater, 2015). Söz konusu yaklaşımın önemi de amacından gelmektedir. Müracaatçının güçlü yönlerine, geçmiş başarılarına ve kazanımlarına odaklanıp kendi gücünün ve değişime yönelik motivasyonunun farkına varmasının, müracaatçı için sorun çözme ve istendik davranış kazanımında olumlu etki yapacağ kabul edilmektedir. Sosyal hizmet uzmanının bu noktada, müracaatçının güçlü yönlerini ortaya çıkarmak, onun kendisine ve gerçekleştirebileceklerine inanmasını sağlamak gibi bir görevi bulunmaktadır. $\mathrm{Bu}$ süreçte sosyal hizmet uzmanının da müracaatçının gücüne ilişkin inançlı olması gerekmektedir. Paradoksal olarak sosyal hizmet uzmanları tarih boyunca meslek elemanı olarak güçsüzlük algısını yansıtmakta iken diğer taraftan sosyal hizmet uzmanları müracaatçlarını güçlendirmek için çaba göstermektedirler (Frans, 1993). Bununla ilgili olarak Teater (2015), sosyal hizmet müdahalesinde müracaatçııı üzerinde çalışılacak 
kişi değil; işbirliği içinde birlikte çalışılacak kişi olarak görmektedir. Bu görüş müracaatçıyı içinde bulunduğu durumun ve deneyimlerinin uzmanı olarak kabul eder ve değişim yapabilecek motivasyona ve gerekli güçlere sahip olduğuna inanır. Çünkü sosyal hizmet mesleği sorunlardan ve patolojilerden ziyade bireylerin güçlerine ve kaynaklarına odaklanmaktadır (Duyan, 2010; Duyan vd., 2008).

Sosyal eylem ideolojisi ve kendi kendine yardım bakış açısı ile büyüyen bir nosyon olarak nitelendirilen güçlendirme kavramı, genellikle müracaatçı gruplarını tanımlama amacı ve hedefi olarak kullanılmıştır. Ancak bu kavram aynı zamanda insani hizmetler çalışanları ile de ilişkilidir (Frans, 1993). Bu noktada literatürde güçlendirmenin çeşitli boyutlarından bahsedilmektedir. Örneğin Speer ve Peterson (2000) güçlendirmenin bilişsel, duygusal ve davranışsal boyutlarına vurgu yapmaktadır. Frans (1993) ise güçlendirmenin hem geleneksel olarak ezilen/baskı altındaki nüfus için hem de sosyal hizmet uzmanları için bilgi ve beceri, kolektif kimlik, eleştirel farkındalık, harekete geçme ve benlik kavramı gibi boyutlarını içerdiğini ifade etmektedir. Bir diğer görüşe göre güçlendirmenin anlamlandırma, yeterlilik hissi, seçim ve etki yapabilme gibi boyutlara sahip olduğu belirtilmektedir (Thomas ve Velthouse, 1990). Bu çalışmada güçlendirmenin boyutları Frans (1993) tarafından belirtilen noktalar üzerinden gidecektir. Aşağıda bu boyutlara ilişkin detaylı açıklamalar yer almaktadır.

\section{Kolektif Kimlik}

Kolektif bir kimlik, bazı özelliklere sahip olan (veya sahip olduğuna inanılan) bir grup insanla paylaşılan kimliktir (Ashmore vd., 2004) ve kişinin öznel talebi veya kabulüyle tanımlanmaktadır. Kolektif bir kimlik için kişinin kendini bir birliktelikle tanımlaması bir ön koşuldur (Deaux, 1996). Bu kavram biz duygusunun ve ait olmanin hatırlatıcısıdır (De Vos, 1995; Ogbu, 2004; Simon ve Klandermans, 2001; Snow, 2001; Spicer, 1971). Bu çerçevede kolektif kimlik değer ve duygusal önem içerir (Tajfel, 1982). Ayrıca paylaşılan bu ortaklık, diğer kişilerle doğrudan temas veya değişim gerektirmez; aksine, ortaklığın psikolojik bir tarafı vardır (Ashmore vd., 2004). Bu tür bir ortaklık, etnisite, cinsiyet, meslek ve siyasi parti gibi hususlara dayandırılabilir (Anthias, 2002; Simon ve 
Klandermans, 2001) ve davranışsal etkilere sahiptir. Dil kullanımı gibi grup üyeliğini yansitan bireysel eylemler, kolektif kimlikle kastedilen şeyin bir parçasıdır (Ashmore vd., 2004). İnsanlar kolektif kimliğini, tutumları, inançları, duyguları, davranışları ve dil veya lehçelerini yansıtan amblemler veya kültürel sembollerle ifade eder (De Vos, 1995; Spicer, 1971).

Sosyal hizmetin amacının hem bireyler arasındaki dayanışmayı hem de toplumdaki dayanışmayı yükseltmek olduğunun belirtilmesi (Adams vd., 2015) kolektif kimlik ile örtüşmektedir. İşbirliği, kolektif kimlikte vurgulanan kavramlar arasındadır (Hardy vd., 2005). Sosyal hizmet uzmanlarının dünya çapında işbirliği, dayanışma ve ortaklaşa çalışmaya bağlı kaldıkları belirtilmektedir (Elliott, 1997). Sosyal hizmet, refah sistemi içerisindeki hizmetlerin bir takım bilgi, beceri ve değer tabanında ve daha insancll bir şekilde yerine getirilmesi ve sosyal adaletin gerçekleştirilmesi noktasında kilit bir roldedir (Kut, 1988; Küçükkaraca, 2004; Şahin, 2000). Sosyal hizmet uzmanlarının etik yükümlülükleri sosyal adalet için çalışmayı içermekte ve bununla bağlantılı olarak toplumdaki kaynakların adaletli dağıtılması hususunda etkin rol alması vurgulanmaktadır (International Federation of Social Workers vd., 2012; Özcan vd., 2017). Kişinin, işlevsel bir parçası olduğu sosyal sistemlerin amaçlarını, kaynaklarını ve isteklerini paylaştığı bir kolektif kimlik duygusu (Frans, 1993) üzerinde önemle durulmaktadır.

Kolektif kimliğin güçler temelli yaklaşımda sunulan işbirliğine dayalı güç ve işbirliği içinde çalışma ile bağlantılı olduğu söylenebilir. Bunun, ortaklığın ve kolektif bir yaklaşımın temeli olduğu vurgulanmaktadır. Bireylerin amaçlarına ulaşmak için kolektif biçimde çalışabileceği ifade edilmektedir. Yani bireylerin uyumu içindeki kolektif gücün, değişimi ortaya çıkarmak için yalnız başına olan çabalardan daha büyük etkisi olduğu (Thompson, 2016) belirtilmektedir. Kolektif kimlik, grup üyeliği bağlamında gücün ya da güçsüzlüğün algilanma eğilimine işaret etmektedir. Bir bütün olma (kolektiflikler) yoluyla üretilen güç, birikimli ve karşılıklı etki yoluyla bireyleri daha derinden ve kalıcı bir şekilde etkilemektedir (Frans, 1993). Ek olarak kolektif kimliğin, sosyal değişimi amaçlayan diğer kolektif faaliyetleri de etkilediği belirtilmektedir (Weerd ve Klandermans, 1999). 


\section{Bilgi ve Beceri}

Sosyal hizmet uzmanlarının kişisel ve mesleki güç algısında bilgi ve becerinin önemi üzerinde ortak görüş bulunmaktadır (Fetterman vd., 1996; Frans, 1993; Hepworth vd., 2016; Pinderhughes, 1983; Sherman ve Wenocur, 1983; Solomon, 1976). 'Bilgi güç'tür ifadesinin yerleşmiş bir düşünce olduğu belirtilmektedir (Thompson, 2016). Ayrıca bir mesleğin gücünün, bilgi tabanından geldiği belirtilmektedir (Lindsey, 1999).

Mesleğin uygulamalarında kullanılan kuramların ve yaklaşımların temel bilgi ve uygulama zemini hazırladığı, kuram ve yaklaşımların temelini anlamaya başlamanın sosyal hizmet uzmanlarının daha bilgili ve etkili olabilmesi için olmazsa olmaz bir husus olduğu vurgulanmaktadır (Teater, 2015). Sheafor and Horejsi (2014) sosyal hizmet uzmanı için şu ifadeleri kullanmaktadırlar:

- "Mesleki eğitime (bilgi, etik ve yeterlilik vb.) sahip olmanın yanı sıra muhtaç durumdaki kimseleri (çocuklar, yaşlılar, yoksullar, azınlıklar ve engelliler gibi) ya da çevredeki insanları veya ilgili sosyal yapıları değiştirmek için çabalayan diğer insanlara hizmet sağlayabilmek ve yardım edebilmek için gerekli olduğu kabul edilen niteliklere sahip olmalıdır."

- "Böylece sosyal hizmet uzmanı, bahsi geçen grupların ve bireylerin kendi sosyal ihtiyaçlarını karşılayabilmelerini, zorluklardan kaçınabilmelerini veya kendilerini geliştirebilmelerini, böylelikle tatmin edici bir yaşam sürebilmelerini ve topluma tamamı ile katkı verebilmelerini sağlamalıdır."

Sosyal hizmet uzmanının kendi veya başkalarının hayatlarındaki olayları etkilemek için yeterli bilgi ve beceriye sahip olması gerektiği vurgulanmaktadır (Frans, 1993). Sosyal hizmetin gerçekleştirilebilmesi için üzerinde düşünülmesi, zaman harcanması gerektiği, mekanik bir şekilde yapılamayacağ belirtilmekte olup (Adams vd., 2015) bunun için de bir bilgi temeline ihtiyaç duyulduğu, bu bilginin de uygulayıcılar, kuramcılar ve araştırmacılardan miras olarak kaldığı ifade edilmektedir. Sosyal hizmet uzmanı, bir yandan bu bilgilere yaslanmalı, diğer yandan bu bilgileri olduğu gibi kabul etmemelidir. Bu bilgi temelinin geniş, karmaşık ve daima gelişmekte olduğu unutulmamalıdır (Thompson, 2013). 
Sosyal hizmette bilgi temeli, var olan bilgilerin, bilimsel bulguların, değerlerin, becerilerin, bilinen şeyi edinme, kullanma ve değerlendirme yöntemlerinin bir araya toplanması olarak ifade edilebilir. Bilgi tabanı, sosyal hizmet uzmanının kendi araştırması, teori oluşturma ve ilgili fenomenlerin sistematik olarak incelenmesinden ve diğer sosyal hizmet uygulayıcılarının doğrudan ve bildirilmiş deneyimlerinden ve müracaatçılar ve diğer disiplinlerin meslek elemanları ve üyeleri tarafından sağlanılan bilgilerden ve bir bütün olarak toplumun genel bilgisinden elde edilmiştir (Barker, 1995; Imre, 1984; Parton, 2006; Trevithick, 2008). Buna bağlı olarak sosyal hizmet uzmanlarının, aşağıdaki alanların bir kısminda veya tamamında bilgiye sahip olması gerektiği belirtilmektedir (NASW, 1982): Bireylerle ve gruplarla sosyal hizmet teori ve teknikleri, topluluk kaynakları ve hizmetleri, yerel ve ulusal sosyal hizmetler ve bu hizmetlerin amaçları, topluluk örgütleri teorileri, sağlık ve refah hizmetlerinin geliştirilmesi, belli başlı sosyo-ekonomik ve politik teoriler, toplumdaki ırksal, etnik ve diğer kültürel grupların değerleri ve yaşam biçimleri ve çağdaş yaşamda ortaya çıkan sorunlar, uygulamaya özel mesleki ve bilimsel araştırma kaynakları, sosyal planlamanın kavram ve teknikleri, süpervizyon teorileri ve kavramları ve sosyal hizmet uygulamasının mesleki süpervizyonu, personel yönetimi teorileri ve kavramları, yaygın sosyal, psikolojik, istatistiksel ve diğer araştırma yöntemleri ve teknikleri, sosyal refah yönetimi teorileri ve kavramları, hizmet edilecek müracaatçları etkileyen sosyal ve çevresel faktörler, psiko-sosyal değerlendirme ve müdahale teorileri ve yöntemleri, ayırıcı tanı teorileri ve yöntemleri, örgütsel ve sosyal sistem teorileri, değişimin özendirilmesi için yöntemler, topluluk örgütlenmesi ile ilgili teori ve teknikler, savunuculuk teori ve teknikleri, sosyal hizmet mesleğinin etik standartları ve uygulamaları, eğitim-öğretim teori ve teknikleri, sosyal refah eğilimleri ve politikaları ve sosyal ve sağlık hizmetlerini etkileyen yerel ve ulusal düzeydeki yasa ve yönetmelikler.

Thompson (2013) sosyal hizmet uzmanının bilmesi gerekenleri sekiz başlık altında sıralamaktadır. Bunlar; insan gelişimi (bireylerin yaşam döngüsündeki evre, sorun ve güçlüklerin neyden kaynaklandığının belirlenmesi ve bu sorun ve güçlüklere çözüm geliştirebilme açısından önemlidir), din ve tinsellik, sosyal süreçler ve kurumlar, kişilerarası ilişkiler, grup ve örgüt dinamikleri, sosyal hizmet süreci (ön değer- 
lendirme, müdahale, gözden geçirme, sonlandırma, değerlendirme), kuramsal paradigmalar, müdahale yöntemleri (bireyle, aileyle, grupla, toplulukla çalışma), etik ve değerlerdir.

Sosyal hizmet sözlüğünde beceri, bir kişinin bilgisini, yeteneklerini, kişiliğini veya kaynakları kullanma yeterliliği olarak tanımlanmaktadır. Bir sosyal hizmet uzmanının becerileri, iletişim konusunda yeterli olmayı, problemleri ve müracaatçının katılımını değerlendirmeyi, ihtiyaçları kaynaklarla eşleştirmeyi, kaynakları geliştirmeyi ve sosyal yapıları değiştirmeyi içermektedir (Barker, 1995). Beceri bir etkinliği belirli bir süre boyunca hem etkili hem de tutarlı bir şekilde yerine getirebilme ile ilgili iken beceri ile ilgili temel vurgu bir beceriye sahip olma ya da olmama değil, becerinin zamanla geliştirilebilme ve öğrenilebilme niteliğine yöneliktir. Bunun dışında sosyal hizmet eğitiminde becerinin (1) var olan becerileri güçlendirme, (2) yeni becerileri geliştirme olmak üzere iki temel bileşeni olduğundan bahsedilmektedir (Thompson, 2013).

NASW, sosyal hizmette 12 temel becerinin olduğunu belirtmektedir (NASW, 1982). Bu becerileri Middleman ve Wood (1990) algılama ve kavramaya dönük içsel beceriler, duygu ve bilgilerle başa çıkma ve görüşme ortamını hazırlama gibi etkileşimsel beceriler ve son olarak çatışma ile başa çıkma, davranışı ele almaya dönük stratejik beceriler olmak üzere üç kısımda incelemişlerdir. Bunlar (NASW, 1982): Anlayışlı ve amaçlı bir şekilde başkalarını dinlemek, sosyal inceleme, değerlendirme ve rapor hazırlamak için bilgileri ortaya çıkarmak ve konu ile ilgili unsurları birleştirmek, profesyonel yardım ilişkisini oluşturmak ve sürdürmek, sözlü ve sözsüz davranışları gözlemlemek, yorumlamak ve kişilik teorisi ve müdahale yöntemleri hakkındaki bilgiyi kullanmak, müracaatçıların kendi sorunlarını kendilerinin çözebilmeleri ve güven kazanabilmeleri için müracaatçlların mücadele etmesini desteklemek, hassas ve duygusal konuları destekleyici ve tehdit olmaksızın tartışmak, müracaatçıların ihtiyaçlarına yenilikçi ve yaratıcı çözümler üretmek, terapötik ilişkiyi sona erdirme ihtiyacını belirleyebilmek, araştırma yapmak veya araştırma bulgularını ve mesleki literatürü yorumlamak, çatışan taraflar arasında arabuluculuk ve müzakere yapmak, kuruluşlar arası bağlantı hizmetleri sağlamak, sosyal ihtiyaçlara ilişkin finansman kaynakları temin etmek, kamu veya kanun koyucularla temas kurmak ve bu kaynakları yorumlamak biçiminde sıralanmaktadır. Bu temel 
beceriler dışında sosyal hizmet uzmanları anlaşılır bir biçimde konuşmalı ve yazmalı, müracaatçılara öğretebilmeli, kriz ya da duygu yüklü durumlarda destekleyici yanttlar verebilmeli, mesleki ilişkisinde rol model olarak hizmet verebilmeli, karmaşık psikososyal olguları yorumlamalı, belirlenmiş sorumlulukları yerine getirmek için bir iş yükü programı düzenlemeli, başkalarına yardımcı olmak için gerekli kaynakları belirlemeli ve elde etmeli, kendi performanslarını ve duygularını değerlendirebilmeli, yardım veya konsültasyon kullanmalı, grup faaliyetlerine katılmalı veya grup faaliyetlerine liderlik etmeli, çatışmacı durumların ya da kavgacı kişiliklerin üstesinden gelebilmeli, sosyal ve psikolojik teorileri uygulama ile bağlantılandırabilmeli, bir sorunu çözebilmek için gerekli olan bilgileri tanımlayabilmeli, kendi uygulamaları ya da ilgili kuruluş hizmetleri için araştırma çalışmaları yürütmelidir.

Thompson (2013) ise bu becerileri 16 başlık altında toplamış ve bunları iletişim becerileri, öz-farkındalık becerileri, analitik beceriler, duyguların yönetilmesi, öz-yönetim becerileri, sunum becerileri, koordinasyon becerileri, duyarlılık ve gözlem becerileri, düşünme becerileri, yaratıcılık, hızlı düşünüp doğru tepki vermek, alçakgönüllülük, yılmazlık, birlikte çalışma becerileri, etkileme becerileri, çatışma yönetimi becerileri olarak ifade etmiştir.

\section{Benlik Kavramı}

Benlik kavramı bireyin öz-değerlendirmesine kök salmış kişisel ve mesleki güç algısının daha geleneksel görünümünü kapsamaktadır (Frans, 1993). Olumlu kendilik değeri ve kendine güven kişisel ve mesleki güç alg1sı sürecinin bu boyutunun merkezindendir. Bireyin kendini nasıl gördüğü (Roger, 1951), kendisi ile ilgili genel kanaati, algıları ve bakış açısı (Aydın, 1996; Bong ve Skaalvik, 2003; Pescitelli, 1996) olarak tanımlanmakta ve olumlu kendilik değerinin ve kendine güvenin, gerekli saygınlığın ve kontrol duygusunun gelişiminde öncü olduğu belirtilmektedir (Pinderhughes, 1983). Benlik kavramı, benliğin statik algısı ile sınırlamaz aksine bireyi sosyal çevrede aktif bir katılımcı olarak tanımlar (Frans, 1993). Benlik kavramının bizi diğerlerinden ayırdığı ve bize özel bir alan oluşturduğu belirtilmektedir (Yener ve Gülaçtı, 2010). 
Benlik kavramı "şahsın kendisi ile ilgili algılamalarının, kişisel atıflarının (yüklemelerinin), geçmiş yaşantılarının, gelecekle ilgili hedeflerinin, sosyal rollerinin onun zihninde temsil edilişidir" (Aydın, 1996). Kişisel değerlerin, inançların ve davranışların biçimlenmesi üzerindeki önceki yaşam deneyimlerinin potansiyel etkisi hakkında farkında olmayı da içermektedir (Lafrance vd., 2004). Bu kavram, pozitif ve bireyi tatmin eden, öz-saygı ve kendini onaylama anlayışına sahip bir bireye (Frans, 1993) vurgu yapmaktadır. Öz-sayg1 ile ilgili olumsuz değerlendirmenin başta duygusal sorunlar olmak üzere içe kapanmaya ve suça yol açabileceği belirtilmektedir (Glasser, 2003). Bireylerin yaşadıkları değersizlik, yetersizlik, başarısızlık ve düşük kendine saygı duygularının bazı sapma davranışlarına neden olabileceği, olumlu kendilik değerlendirmesi için güçlü yanların ön plana çıkarılması gerektiği, güçlü yanların ön plana çıkarılmasının benlik kavramını da olumlu bir şekilde etkilediği belirtilmektedir (Duyan vd., 2008). Bu noktada sosyal hizmet uzmanlarının sosyal hizmet uygulamasında kendisini doğrudan bir uygulama aracı olarak kullandığı bu nedenle de öz saygisının önemli olduğu söylenebilir.

\section{Eleştirel Farkındalık}

Sosyal hizmet uzmanlarının kişisel ve mesleki güç algısının bir başka bileşenin ise eleştirel farkındalık olduğu belirtilmektedir. Eleştirel farkındalık köken olarak incelediğinde eleştirinin, bir insanı, bir eser veya bir konuyu doğru ve yanlış yanlarını bulup göstermek amaciyla inceleme işi; farkındalığın ise ele almak, sezmek ve ayırt etmek anlamına geldiği görülecektir (TDK, 2017).

Sosyal ve politik gerçekler hakkında eleştirel bir bakış açısı elde etmek için bilgi ve kapasite oluşturma konusu güçlendirmenin merkezine aldığ1 konulardandır (Lee, 2001). Eleştirel düşünme, "sosyal hizmet uzmanları tarafından yararlanılan, kesin cevaplar bulamadığımızda mevcut sorun hakkındaki inandıklarımızın bu inanışları kullanmamızı gerektirip gerektirmediğine karar vermelerine yarayan bir süreç olarak" tanımlanır (Sheafor ve Horejsi, 2014). Diğer bir ifade ile birisinin dünyası ile ilgili çok yönlü muhakeme yapabilme ve oluşturabilme becerisi olarak tanımlanmaktadır (Frans, 1993). Eleştirel bakış açısının sosyal 
hizmet uzmanları için olmazsa olmaz olduğu, aksi takdirde uzmanların baskı ve eşitsizliklere karşı gelmek bir yana baskı ve eşitsizlikleri daha da alevlendirebileceği belirtilmektedir (Preston-Shoot, 1996). Eleştirel farkındalığın baskının ulusal ve uluslararası boyutlarının anlaşılmasında yol gösterici bir noktada olduğu belirtilmektedir (İçağasığlu-Çoban ve Buz, 2008). Bu noktada Zastrow (2013) sosyal hizmet uzmanlarının yüksek düzeyde eleştirel farkındalığa sahip olması gerektiğini vurgulamaktadır. Adams ve diğerleri (2015) eleştirel bakış açısı ile ilgili şu ifadeleri kullanmaktadırlar:

"...güç, baskı ve eşitsizlik kavramlarının kişisel ve yapısal ilişkileri nasıl belirlediğinin anlaşılmasına dayanır. Uygulayıcılar, sosyal olarak yapılanmış ırk, cinsiyet, sinff, cinsellik, yaş ve engellilik gibi bölünmelerin ve kaynaklara farkl yollardan erişimin toplumun ve bireylerin yaşam tecrübelerini nasıl etkilediğgini analiz etmekle yükümlüdür... Tüm sosyal hizmet uzmanları, çalıştıklarn toplumun politika ve siyasetini, değerler ve sosyal varsayımların sorgulamak zorundadırlar. Toplumlarımızın yoksulluk içindeki ya da diğer zorluklarla yüzleşen insanlarının iyilik hallerini sağlama ve geliştirme çabalarının bir parçası olduğumuz için, yardımo olmak üzere çă̆rıldı̆̆ımız zorlukların ortaya çıkmasına sebep olan toplumsal koşulları tanımlamak, onlara karşı çıkmak ve değiştirmeye çalışmak, mesleki rolümüzün ayrllmaz bir parçasdır."

Sosyal hizmet uzmanları bir taraftan bireysel ve mesleki gücünü sürdürmeye çalışırken diğer taraftan müracaatçıları güçlendirme girişiminde bulunmaktadır. Sosyal hizmet uzmanlarının yaşadığı ikilemleri hafifletmek amaciyla Pinderhughes (1983) güçlendirmenin, sosyal hizmet uzmanının hayırsever konumundan vazgeçtiğinde ve kendisi ve müracaatçılarının yaşamları üzerinde daha eleştirel bir bakış açısı kazandığında ortaya çıktığını ifade etmektedir. Bu noktada bireyin dünyadaki yerinin daha büyük sistemlerle ya da makro yapılarla ilgili olduğu konusundaki eleştirel farkındalığı olmamasının uzmanın kişisel ve mesleki güç algısı önünde engel oluşturduğu belirtilmektedir (Frans, 1993). Eleştirel farkındalığın yaşadığımız dünyanın arkadasındaki bilgiye bakışta farkındalık kazandırması, olanın ötesini görmeyi kolaşlaştırması, aydınlatıcı ve özgürleştirici yeni bir çerçeve sunması önemli özellikleri olarak karşımıza çıkmaktadır (İçağasıoğlu-Çoban ve Buz, 2008). Eleştirel bakış açısının beninsenmemesinin, görece daha güçsüz konumdaki bireylerin kendi güçsüzlükleri içerisinde sıkışmalarına sebebiyet vereceği 
üzerinde durulmaktadır (Thompson, 2013). Örneğin literatürde düşünümsel uygulamadan bahsedilmekte ve bu uygulamanın eleştirel olmayan, rutinleşmiş uygulamaya karşı çıktığı, eleştirel bakış açısının bu uygulamanın yapı taşı olduğu, diğer türlü dezavantajlı ve eşitsiz örüntülerin pekiştirilebileceği (Adams vd., 2015; Burke ve Dalyrmple, 2015; Thompson, 2013) ifade edilmektedir. Sheafor ve Horejsi (2014) başarılı bir uygulama için iki temel unsurdan birinin müracaatçlara müdahale aşamalarında rehberlik etmek için uzmanların eleştirel düşünebilme ve yeteneğine sahip olması gerektiğinin altını çizmektedir. Örneğin yoksulluk sorununu ele aldığımızda sosyal hizmet uzmanlarının bireylerin bu sorunla karşı karşıya kalmasının yapısal nedenlerini anlamalı, müracaatçıların gereksinimlerini buna göre şekillendirmeli ve yoksulluğun nedenleri ile ilgili yapısal ve makro çözümlemeler noktasında eleştirel çerçevede hareket etmelidir (İçağasığlu-Çoban ve Buz, 2008).

\section{Harekete Geçme}

Sosyal hizmet uzmanlarının kişisel ve mesleki güç algısının diğer bileşeni ise harekete geçme eğilimidir. Harekete geçme eğilimi, daha iyi ve dengeli güç ilişkilerine ulaşmaya doğru yönlendirilmiş yansitıcı eylemler olarak tanımlanmaktadır (Torre, 1986). Nereden bakilırsa bakılsın sosyal hizmet uzmanlarının tüm çalışmaları eyleme dönüktür. Tüm çalışmalarında harekete geçme noktasında hazır bir şekilde bekledikleri söylenebilir. Uzmanların memur olmak yerine meslek elemanı olmayı tercih ettikleri Acar ve diğerlerinin (2017) yapmış olduğu araştırmada bulgulanmıştır. Diğer bir ifade ile sosyal hizmet uzmanlarının sosyal hizmet uygulamasında harekete geçme noktasında kişisel ve mesleki olarak içsel bir motivasyona sahip olduğu söylenebilir. Literatürde uygulamanın karşılaşma, ön değerlendirme, planlama, uygulama, uygulamayı değerlendirme (sonlandırma ve izleme) gibi kimi kaynaklarda beş kimi kaynaklarda yedi çekirdek işlevi (Gelman ve Mirabito, 2005; Kirst-Ashman ve Hull, 2008; Miley vd., 2016; Popple ve Leighninger, 2011; Poulin, 2000) daha iyi ve dengeli güç ilişkilerine ulaşmaya doğru yönlendirilmiş yansıtıcı eylemlere örnek olarak gösterilebilir. Böylece güçlendirilmiş bireylerin kendileri için daha anlamlı 
faaliyetler içerisinde olacakları varsayılmaktadır (Frans, 1993). Diğer bir ifade ile sosyal hizmet uzmanlarının müracaatçılara güç paylaşımı yaparak ve kaynakları harekete geçirerek yardımcı olabilecekleri belirtilmektedir (Pinderhughes, 1983). Bu noktada Frans (1993) sosyal hizmet uzmanının kendisi ve diğerleri adına etkili eylem başlatma becerisine sahip olması gerektiğinin altını çizmektedir.

\section{Sonuç}

Literatürde güçlendirmenin çeşitli boyutlarından bahsedilmektedir (Frans, 1993; Speer ve Peterson, 2000; Thomas ve Velthouse, 1990). Ancak bu çalışmada Frans (1993) tarafından ortaya atılan ve bugüne kadar Türkçe literatürde yer almayan güçlendirmenin boyutları ele alınmıştır. Bu boyutlar kolektif kimlik, bilgi ve beceri, benlik kavramı, eleştirel farkındalık ve harekete geçme üzerine inşa edilmiştir. Frans (1993) güçlendirme konusunda bu boyutların hem müracaatçlar hem de sosyal hizmet uzmanları için geçerli olduğunu vurgulamaktadır. Güçlendirme konusu gündeme geldiğinde bu konu çoğu zaman geleneksel olarak ezilen/baskı altındaki nüfus için düşünülmektedir. Geleneksel olarak ezilen/baskı altındaki nüfus grubu göz önünde tutulurken, bu nüfus gruplarına hizmet vermekte olan sosyal hizmet uzmanları göz ard1 edilebilmektedir. Bununla bağlantılı olarak güçlendirmenin boyutları sosyal hizmet uzmanı perspektifinden ele alınmaya çalışılmıştır. Benzer bir şekilde literatürde bahsedilen diğer boyutların da yine sosyal hizmet uzmanı perspektifini göz önünde tutarak değerlendirilmesi önerilmektedir. 


\section{EXTENDED ABSTRACT}

\section{A Strength Based Approach and Empowerment: Collective Identity, Knowledge-Skills, Self-Concept, Critical Awareness, Propensity to Act \\ * \\ Mehmet Kirlıŏglu \\ Necmettin Erbakan University}

This study aims to address the concept of empowerment by considering various aspects of a strength based approach. Although the concept of empowerment is widely included in the Turkish literature, the dimensions of collective identity, knowledge and skills, self concept, critical awareness and propensity to act have not been previously addressed. It is thought that these dimensions, which are thought to add richness to the concept of empowerment, will benefit both the social work literature and the practices of social workers. A strength based approach emerged based on social constructivist view. A strenght based approach is a way of working that directs the social worker towards interactions and interventions focusing on powers, skills, resources and achievements rather than focusing on the problems or flaws of the clients. In determining the clients' strengths, social workers should focus beyond the apparent powers of the clients. Furthermore, capacities, competencies, character, promise, possibility, resources, resilience, reserve of the clients should be carefully reviewed. On the other hand, the idea that there is power within the individual is a starting point in terms of empowerment. It is important that these two concepts, which are thought to be related to each other, be handled together. Various aspects of empowerment are mentioned in the literature. In this study, the dimensions of empowerment are explained through five dimensions conceptualized by Frans (1993). These dimensions are called collective identity, knowledge and skills, self concept, critical awareness and propensity to act.

Stating that the aim of social work is to increase both solidarity among individuals and solidarity in society coincides with collective identity. Cooperation is among the concepts emphasized in collective 
identity. It is stated that social workers are committed to cooperation, solidarity and collaborative work around the world. It is emphasized that this is the basis of partnership and a collective approach. It is stated that individuals can work collectively to achieve their goals.

There is a common opinion on the importance of knowledge and skills in the perception of personal and professional power of social workers. It is stated that the expression of 'knowledge is power' is an established thought. It is also stated that the strength of a profession comes from the knowledge base. It is emphasized that the theories and approaches used in the practice of the profession provide the basis of knowledge and practice, and that understanding the basis of the theories and approaches is essential for social workers to be more knowledgeable and effective. In the social work dictionary, skill is defined as the ability of a person to use his / her knowledge, abilities, personality or resources. The skills of a social worker include being competent in communication, assessing problems and client participation, matching needs with resources, improving resources and changing social structures.

The self concept encompasses a more traditional view of the individual's perception of personal and professional power rooted in selfevaluation. Positive self-esteem and self-confidence are central to this dimension of the perception of personal and professional power. The self concept is defined as how an individual sees himself, his / her general opinion, perceptions and point of view, and it is stated that positive selfesteem and self-confidence lead to the development of necessary dignity and sense of control.

Another component of the perception of personal and professional power of social workers is critical awareness. When critical awareness is examined as the origin of criticism, it is the work of review to find and show the right and wrong sides of a person, a work or a subject; and awareness means taking, perceiving and distinguishing. Knowledge and capacity building are central to strengthening to gain a critical perspective on social and political realities. Critical thinking is defined as a process used by social workers to help us decide whether or not we believe in the current problem if we do not find definite answers.

Another component of the perception of personal and professional power of social workers is the propensity to act. The propensity to act is 
defined as reflective actions directed towards achieving better and balanced power relations. Regardless of all the work of social workers are action oriented. It can be said that they are ready to take action in all of their works. In the literature, some core sources of practice such as engagement, assessment, planning, intervention, evaluation (termination and monitoring) can be cited as examples of reflective actions directed towards achieving better and balanced power relations. Thus, it is assumed that empowered individuals will engage in more meaningful activities for themselves. It is suggested that the other dimensions mentioned in the literature should be evaluated by considering the perspective of social worker.

\section{Kaynakça / References}

Acar, H., İçağasığlu-Çoban, A. ve Polat, G. (2017). Sosyal hizmetlerde yanlış uygulamalar, etik ihlaller ve sorunlara ilişkin bir araştırma. Ankara: Türkiye Felsefe Kurumu Derneği.

Adams, R. (2003). Social work and empowerment. New York: Palgrave Macmillan.

Adams, R., Dominelli, L. and Payne, M. (2015). Eleştirel bir sosyal anlayışına doğru. In (R. Adams, L. Dominelli, M. Payne Eds.), Sosyal hizmet: Temel alan ve eleştirel tartışmalar. Ankara: Nika Yayınevi.

Anthias, F. (2002). Where do I belong? Narrating collective identity and translocational positionality. Ethnicities, 2(4), 491-514.

Anuradha, K. (2004). Empowering families with mentally ill members: A strengths perspective. International Journal for the Advancement of Counselling, 26(4), 383-391.

Ashmore, R. D., Deaux, K. and McLaughlin-Volpe, T. (2004). An organizing framework for collective identity: articulation and significance of multidimensionality. Psychological Bulletin, 130(1), 80-114.

Aydın, B. (1996). Benlik kavramı ve ben şemaları. M.Ü. Atatürk Eğitim Fakültesi Eğitim Bilimleri Dergisi, 8, 41-47.

Barker, R. L. (1995). The social work dictionary. Washington, DC: National Association of Social Workers.

Berger, P. and Luckmann, T. (1967). The social construction of reality Harmondsworth. Harmondswoth: Penguin. 
Blum, D. (1998). Finding strength: How to overcome anything. Psychology Today, 31(3), 32-38.

Bong, M. and Skaalvik, E. M. (2003). Academic self-concept and self-efficacy: How different are they really? Educational psychology review, 15(1), 140.

Burke, B. and Dalyrmple, J. (2015). Eleştirel müdahale ve güçlendirme. In (L. D. R. Adams, M. Payne, Ed.), Sosyal hizmet: temel alanlar ve eleştirel tartışmalar. Ankara: Nika Yayınevi.

Cade, B. and O'Hanlon, W. H. (1993). A brief guide to brief therapy. New York: Norton.

Canda, E. R. (2006). The future of spirituality in social work: The farther reaches of human nurture. Advances in Social Work: Special Issue on the Futures of Social Work, 6(1), 97.

Chapin, R. K. (1995). Social policy development: The strengths perspective. Social Work, 40(4), 506-514.

Cowger, C. D. (1994). Assessing client strengths: Clinical assessment for client empowerment. Social Work, 39(3), 262-268.

De Jong, P. and Miller, S. D. (1995). How to interview for client strengths. Social Work, 40(6), 729-736.

De Vos, G. A. (1995). Ethnic pluralism: conflicts and accommodation. In (L. Romanucci-Ross, G. A. De Vos Eds.), Ethnic identity: Creation, conflict, and accommodation (p. 15-41). Walnut Creek, CA: Altimira Press.

Deaux, K. (1996). Social identification. In (E. T. Higgins, A. W. Kruglanski Eds.), Social psychology: Handbook of basic principles (p. 777-798). New York: Guilford Press.

Dubois, B. L., Miley, K. K. (2013). Social work: An empowering profession. New York: Pearson Higher Ed.

Duyan, V. (2010). Sosyal hizmet: temelleri, yaklaşımları, müdahale yöntemleri. Ankara: Sosyal Hizmet Uzmanları Derneği Yayın.

Duyan, V., Özgür-Sayar, Ö. ve Özbulut, M. (2008). Sosyal hizmeti tanımak ve anlamak: Sosyal hizmet uzmanları ve sosyal hizmet alanında çalışanlar için bir rehber. Ankara: Öncü Basımevi.

Elliott, D. (1997). Conclusion. In (N. S. Mayadas, T. D. Watts, D. Elliott Eds.), International handbook on social work theory and practice. Westport, CT: Greeenwood. 
Fetterman, D. M., Kaftarian, S. J. and Wandersman, A. (1996). Empowerment evaluation: Knowledge and tools for self-assessment and accountability. London: Sage.

Frans, D. J. (1993). A scale for measuring social worker empowerment. Research on Social Work Practice, 3(3), 312-328.

Gelman, C. R. and Mirabito, D. M. (2005). Practicing what we teach: Using case studies from $9 / 11$ to teach crisis intervention from a generalist perspective. Journal of Social Work Education, 41(3), 479-494.

Glasser, W. (2003). Warning: Psychiatry can be hazardous to your mental health. New York: HarperCollins Publishers.

Goldstein, H. (1990). Strength or pathology: Ethical and rhetorical contrasts in approaches to practice. Families in Society, 71(5), 267-275.

Greene, G. J. and Lee, M.-Y. (2002). The social construction of empowerment. In (M. O'Melia, K. K. Miley Eds.), Pathways to power: Readings in contextual social work practice (p. 175-201). Boston, MA: Allyn and Bacon.

Gutierrez, L. M. (1990). Working with women of color: An empowerment perspective. Social Work, 35(2), 149-153.

Güdek, K. (2013). Birey ve aile sosyal çalışma. İstanbul: Nobel Tıp Kitabevleri Ltd. Şti.

Hardy, C., Lawrence, T. B. and Grant, D. (2005). Discourse and collaboration: The role of conversations and collective identity. Academy of management review, 30(1), 58-77.

Hepworth, D. H., Rooney, R. H., Rooney, G. D. and Strom-Gottfried, K. (2016). Empowerment series: Direct social work practice: Theory and Skills: Nelson Education.

International Federation of Social Workers, International Association of Schools of Social Work, International Council on Social Welfare. (2012). The global agenda for social work and social development: Commitment to action. Journal of Social Work Education, 48(4), 837843.

İçağasığlu-Çoban, A. ve Buz, S. (2008). Eleştirel teori: Gelişimi, kabulleri ve sosyal hizmette kullanımı. Toplum ve Sosyal Hizmet, 19(1), 71-89.

Imre, R. W. (1984). The nature of knowledge in social work. Social Work, 29(1), 41-45.

Kirst-Ashman, K., Hull, G. (2008). Understanding generalist practice. Belmont, CA: Thomson Brooks. In: Cole Publishing. 
Kut, S. (1988). Sosyal hizmet mesleği: nitelikleri, temel unsurları, müdahale yöntemleri. Ankara:Kendi yayını.

Küçükkaraca, N. (2004). Küreselleşme, sosyal adalet ve sosyal hizmet. Paper presented at the 6. Ulusal sosyal hizmetler konferansı. Küreselleşme, sosyal adalet ve sosyal devlet, 20-22 Mayss 2004, Ankara.

Lafrance, J., Gray, E. and Herbert, M. (2004). Gate-keeping for professional social work practice. Social Work Education, 23(3), 325-340.

Lee, J. A. (2001). The empowerment approach to social work practice building the beloved community. New York: Columbia University Press.

Lindsey, D. (1999). Ensuring standards in social work research. Research on Social Work Practice, 9(1), 115-120.

Middleman, R. R., Wood, G. G. (1990). Skills for direct practice in social work. New York: Columbia University Press.

Miley, K. K., O'Melia, M. W. and DuBois, B. L. (2016). Generalist social work practice: An empowering approach: Pearson.

NASW. (1982). The standards for the classification of social work practice. Silver Spring, Maryland National Association of Social Worker.

Nunnally, E., De Shazer, S., Lipchik, E. and Berg, I. (1986). A study of change: Therapeutic theory in process. Journeys: Expansion of the strategic-systemic therapies, Cilt(say1), 77-96.

Ogbu, J. U. (2004). Collective identity and the burden of "acting white" in Black history, community, and education. The Urban Review, 36(1), 135.

Özcan, E., Özden, S. A. and İçağasıŏlu-Çoban, A. (2017). Sosyal hizmet uzmanlarının güvencesiz çalışma biçimine ilişkin deneyimlerinin değerlendirilmesi. Journal of Human Sciences, 14(1), 376-395.

Parton, N. (2006). Changes in the form of knowledge in social work: From the 'social'to the 'informational'? British Journal of Social Work, 38(2), 253-269.

Payne, M. (2005). Modern social work theory. Chicago: Lyceum Books Inc.

Pescitelli, D. (1996). An analysis of Carl Rogers' theory of personality. http://scholar.googleusercontent.com/scholar?q=cache:MRh7K74uM NMJ:scholar.google.com/+(Pescitelli,+1996)\&hl=tr\&as_sdt=0,5 accessed on 15 April 2018.

Pinderhughes, E. B. (1983). Empowerment for our clients and for ourselves. Social Casework, 64(6), 331-338. 
Popple, P. R. and Leighninger, L. (2011). Social welfare, and American society. Boston: Allyn \& Bacon.

Poulin, J. E. (2000). Collaborative social work: Strengths-based generalist practice. Itasca, IL: F. E. Peacock.

Preston-Shoot, M. (1996). W (h) ither social work? Social work, social policy and law at an interface: Confronting the challenges and realising the potential in work with people needing care or services. Liverpool Law Review, 18(1), 19-39.

Rapp, C. A., Pettus, C. A., Goscha, R. J. (2006). Principles of strengths-based policy. Journal of Policy Practice, 5(4), 3-18.

Roger, C. R. (1951). Client-centered therapy: Its current practice, implications and theory: Houghton Mifflin.

Saleebey, D. (1997). The strengths approach to practice. The strengths perspective in social work practice, 3, 80-93.

Saleebey, D. (2000). Power in the people: Strengths and hope. Advances in social work, 1(2), 127-136.

Saleebey, D. (2006). Power in the people. In (D. Saleebey Ed.), The strenghts perspective social work practice (p. 7-22). Boston, MA: Pearson Education.

Saleebey, D. (2012). The strengths approach to practice: Beginnings. In (D. Saleebey Ed.), Strengths perspective in social work practice (pp. 93-107). New York, NY: Pearson.

Sheafor, B. ve Horejsi, C. (2014). Sosyal hizmet uygulaması temel teknikler ve ilkeler. Ankara: Nika Yayınevi.

Sherman, W. R. and Wenocur, S. (1983). Empowering public welfare workers through mutual support. Social Work, 28(5), 375-379.

Simon, B., Klandermans, B. (2001). Politicized collective identity: A social psychological analysis. American psychologist, 56(4), 319-331.

Snow, D. (2001). Collective identity and expressive forms. https://escholarship.org/uc/item/2zn1t7bj.

Solomon, B. B. (1976). Black empowerment: Social work in oppressed communities. New York: Columbia University Press.

Speer, P. W. and Peterson, N. A. (2000). Psychometric properties of an empowerment scale: Testing cognitive, emotional, and behavioral domains. Social Work Research, 24(2), 109-118. 
Spicer, E. H. (1971). Persistent Cultural Systems: A comparative study of identity systems that can adapt to contrasting environment. Science, 175, 795-800.

Sullivan, W. P. (1992). Reclaiming the community: The strengths perspective and deinstitutionalization. Social Work, 37(3), 204-209.

Şahin, F. (2000). Sosyal hizmet uzmanlarının sosyal refah politikasın süreçlerine katılımı. Ankara: Aydınlar Matbaası.

Tajfel, H. (1982). Social psychology of intergroup relations. Annual review of psychology, 33(1), 1-39.

Teater, B. (2015). Sosyal hizmet kuram ve yöntemleri. Ankara: Nika Yayınevi.

Thomas, K. W. and Velthouse, B. A. (1990). Cognitive elements of empowerment: An "interpretive" model of intrinsic task motivation. Academy of management review, 15(4), 666-681.

Thompson, N. (2013). Kuram ve uygulamada sosyal hizmeti anlamak. Ankara Dipnot Yayınları.

Thompson, N. (2016). Güç ve gü̧̈lendirme. Ankara: Nika Yayınevi.

Torre, D. A. (1986). Empowerment: Structured conceptualization and instrument development. Ithaca: Cornell University.

Trevithick, P. (2008). Revisiting the knowledge base of social work: A framework for practice. The British Journal of Social Work, 38(6), 12121237.

Weerd, M. D. and Klandermans, P. (1999). Group identification and social protest: Farmers' protest in the Netherlands. European Journal of Social Psychology, 29, 1073-1095.

Weick, A., Rapp, C., Sullivan, W. P. and Kisthardt, W. (1989). A strengths perspective for social work practice. Social Work, 34(4), 350-354.

Wolin, S. and Wolin, S. (1998). Shaping a brighter future by uncovering "survivor's pride.". Reaching Today's Youth, 2(3), 61-64.

Wolin, S. J. and Wolin, S. (2010). The resilient self: How survivors of troubled families rise above adversity. United States: Villard Book.

Yener, Ö. ve Gülaçtı, F. (2010). Benlik-kavramı ve benliğin gelişimi bilen benliğe gereksinim var mı? Erzincan Eğitim Fakültesi Dergisi, 12, 2137.

Zastrow, C. (2013). Sosyal hizmete giriş. Ankara: Nika Yayınevi. 


\section{Kaynakça Bilgisi / Citation Information}

Kırlıoğlu, M. (2019). Güçler temelli yaklaşım ve güçlendirme: Kolektif kimlik, bilgi-beceri, benlik kavramı, eleştirel farkındalık, harekete geçme. OPUS-Uluslararası Toplum Araştırmaları Dergisi, 14(20), 2248-2277. DOI: 10.26466/opus.597190 